Supporting Information

\title{
Smart MMP2-Responsive Nanoprobe for Activatable Fluorescence Imaging-Guided Local Triple-Combination Therapies with Single Light
}

Bin-Bin $\mathrm{Hu},{ }^{\dagger}$ Peng-Yun Li, ${ }^{\star}$ Xiao-Xi Yang,${ }^{\dagger}$ Yi-Fan Fan, ${ }^{\dagger}$ Chang-Fu Shan,${ }^{\dagger}$ Ping-Ru Su, ${ }^{\dagger}$ Jing Cao, ${ }^{*}, \dagger$ Bo Cheng, ${ }^{*}, \ddagger$ Wei-Sheng, Liu, ${ }^{\dagger}$ and Yu Tang $*, \dagger$

'State Key Laboratory of Applied Organic Chemistry, Key Laboratory of Nonferrous Metal Chemistry and Resources Utilization of Gansu Province, College of Chemistry and Chemical Engineering, Lanzhou University, Lanzhou 730000, P.R. China.

*Ministry of Education Key Laboratory of Cell Activities and Stress Adaptations, School of Life Sciences, Lanzhou University, Lanzhou 730000, P.R. China

Email: tangyu@1zu.edu.cn; caoj@1zu.edu.cn; bocheng@1zu.edu.cn 


\section{Experimental Details}

Fluorescence restoration triggered by MMP2 in solutions: MMP2 was firstly treated with p-aminophenylmercuric acetate $(2.5 \mathrm{mM})$ for $1 \mathrm{~h}$ in TCNB buffer $(5 \mathrm{mM}$ $\mathrm{CaCl}_{2}, 50 \mathrm{mM}$ Tris, $150 \mathrm{mM} \mathrm{NaCl}, 0.05 \%$ of Brij, $\mathrm{pH}$ 7.4) for the enzyme activation. Then, varying concentrations of activate MMP2 were added into nanoprobe solutions to incubate for another $2 \mathrm{~h}$. The fluorescence emission spectrum of each sample was detected with $\lambda_{\mathrm{ex} / \mathrm{em}}=420 / 682 \mathrm{~nm}$.

Measurement of ${ }^{1} \mathrm{O}_{2}$ production in solutions: ${ }^{1} \mathrm{O}_{2}$ generation of $\mathrm{PPa}$ was measured with DPBF as indicator. Briefly, the indicator was added into nanoprobe solutions with or without MMP2 treatment. Under the laser irradiation, absorption spectra of DPBF were measured. What's more, the absorbance of free DPBF under irradiation was also recorded.

Cell imaging with confocal laser scanning microscopy (CLSM): Both cell lines were grown for $24 \mathrm{~h}$ at $37{ }^{\circ} \mathrm{C}$ in chamber slides, and then incubated with the nanoprobe for another $6 \mathrm{~h}$. After that, residual nanoprobe was removed through washing both cell lines with cold PBS. CLSM was carried out with excitation at 405 $\mathrm{nm}$ and $>650 \mathrm{~nm}$ detection.

${ }^{1} \mathrm{O}_{2}$ generation in vitro: ${ }^{1} \mathrm{O}_{2}$ generation in $\mathrm{HepG} 2$ and $\mathrm{L} 02$ cells was measured using ROS sensitive probe DCFH-DA. After being incubated with nanoprobe, both cell lines were then treated with $30 \mu \mathrm{M}$ of DCFH-DA for another $30 \mathrm{~min}$ at $37^{\circ} \mathrm{C}$. After incubation in dark, use cold PBS to wash the cells. Subsequently, irradiate cells with $660 \mathrm{~nm}$ laser for $3 \mathrm{~min}$. After that, fluorescence images were obtained using 
CLSM with $488 \mathrm{~nm}$ exaction and detection at $525 \mathrm{~nm}$. And the ${ }^{1} \mathrm{O}_{2}$ generation levels could be reflected by fluorescence intensity of DCF produced.

Cell death staining: Therapy efficacy of PTT, PDT, PDT/PTT, and PDT/PTT/CT were evaluated using LIVE-DEAD kits. HepG2 cells were incubated with HAuNs, HAuNs-peptide-PPa or nanoprobe $(5 \mu \mathrm{M} \mathrm{PPa})$ for $6 \mathrm{~h}$. Then wash cells and irradiate them with $660 \mathrm{~nm}$ laser. Calcein AM-PI was used to stain cells. Fluorescence microscope was used to image the cells with exaction at $488 \mathrm{~nm}$. The cytotoxicity of HAuNs, HAuNs-peptide-PPa, DOX@HAuNs-peptide-PPa and laser irradiation were also investigated, as control groups.

Cell cytotoxicity with MTS assay: After being incubated in medium which contains various concentrations of HAuNs or HAuNs-peptide-PPa, HepG2 cells were irradiated with laser $\left(2 \mathrm{~W} \mathrm{~cm}^{-2}, 5 \mathrm{~min}\right.$ or $\left.100 \mathrm{~mW} \mathrm{~cm}^{-2}, 5 \mathrm{~min}\right)$ for PTT or PDT. For PDT/PTT or PDT/PTT/CT, cells treated with HAuNs-peptide-PPa or DOX@HAuNs-peptide-PPa were irradiated (2 $\left.\mathrm{W} \mathrm{cm}^{-2}, 5 \mathrm{~min}\right)$. Cell viability was analyzed by MTS. $0.5 \mathrm{mg} / \mathrm{mL}$ MTS was added in medium to incubate cells for $4 \mathrm{~h}$. Microplate reader was used to measure the absorbance at $490 \mathrm{~nm}$. Additionally, viability of L02 cells with treatment of PDT were monitored. Cytotoxicity of nanoprobe in dark was also studied.

In vivo fluorescence imaging: The mice were injected Huh7 cancer cells to form tumors. When the tumors grow to $120 \mathrm{~mm}^{3}$, tumor-bearing mice were injected with the nanoprobe $\left(6 \mu \mathrm{g} \mathrm{mL} \mathrm{m}^{-1} \mathrm{PPa}\right)$ by intratumoral injection. After 4 and $12 \mathrm{~h}$ post-injection, the mice were anesthetized and scanned to achieve fluorescence 
images with exaction at $405 \mathrm{~nm}$. The in vivo fluorescence imaging was performed on luminalll (PerkinElmer).

In vivo synergistic therapy: Balb/c-nu mice were purchased from Shanghai SLAC Laboratory Animal Co., Ltd. All mice were handled under the protocol approved by the Institutional Animal Care and Use Committee of East China Normal University. The mice were injected Huh7 cancer cells subcutaneously to establish tumors. The tumors were allowed to grow to reach $120 \mathrm{~mm}^{3}$. The tumor-bearing mice were divided into 6 groups, which were treated with PBS + laser irradiation as control, DOX@HAuNs-peptide-PPa in dark, HAuNs + laser irradiation $\left(2 \mathrm{~W} \mathrm{~cm}^{-2}, 5 \mathrm{~min}\right)$ for PTT, HAuNs-peptide-PPa + laser irradiation $\left(100 \mathrm{~mW} \mathrm{~cm}^{-2}, 5 \mathrm{~min}\right)$ for PDT, HAuNs-peptide-PPa + laser irradiation $\left(2 \mathrm{~W} \mathrm{~cm}^{-2}, 5 \mathrm{~min}\right)$ for PDT/PTT, DOX@HAuNs-peptide-PPa + laser irradiation $\left(2 \mathrm{~W} \mathrm{~cm}^{-2}, 5 \mathrm{~min}\right)$ for PDT/PTT/CT. The reagent ( $\left.30 \mu \mathrm{g} \mathrm{mL} L^{-1} \mathrm{HAuNs}, 6 \mu \mathrm{g} \mathrm{mL}^{-1} \mathrm{PPa}\right)$ was injected intratumorally into the mice every three days for three weeks. The body weight changes and tumor volumes were monitored every 3 days after treatment. The following equation was used to calculate the tumor volume:

$$
\mathrm{V}=\frac{\mathrm{AB}^{2}}{2}
$$

where A and B are the longer and shorter diameter $(\mathrm{mm})$ of the tumor, respectively. 


\section{Supporting Figures}

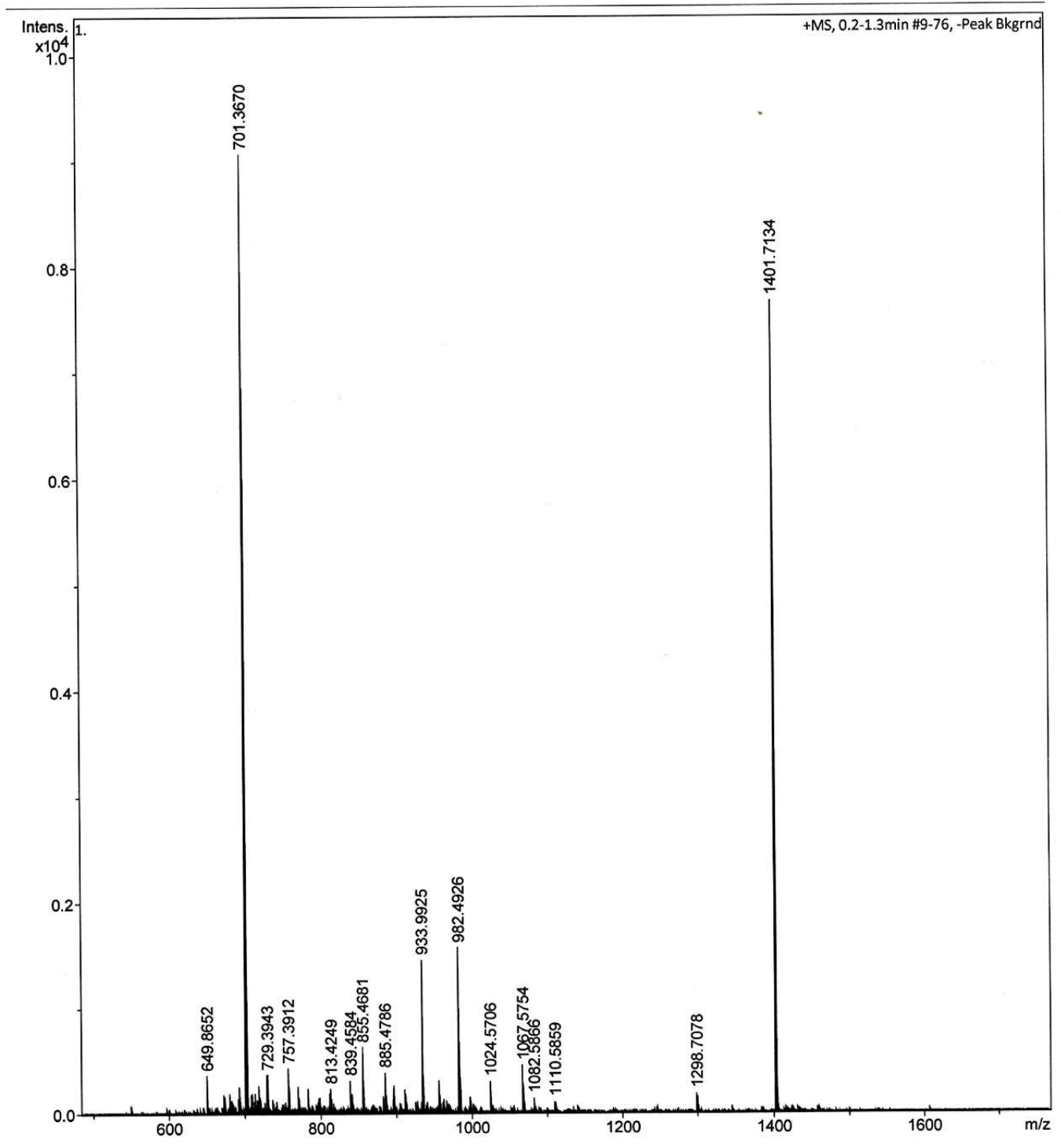

Figure S1. ESI-MS characterization of CGPLGVRGK-PPa. 


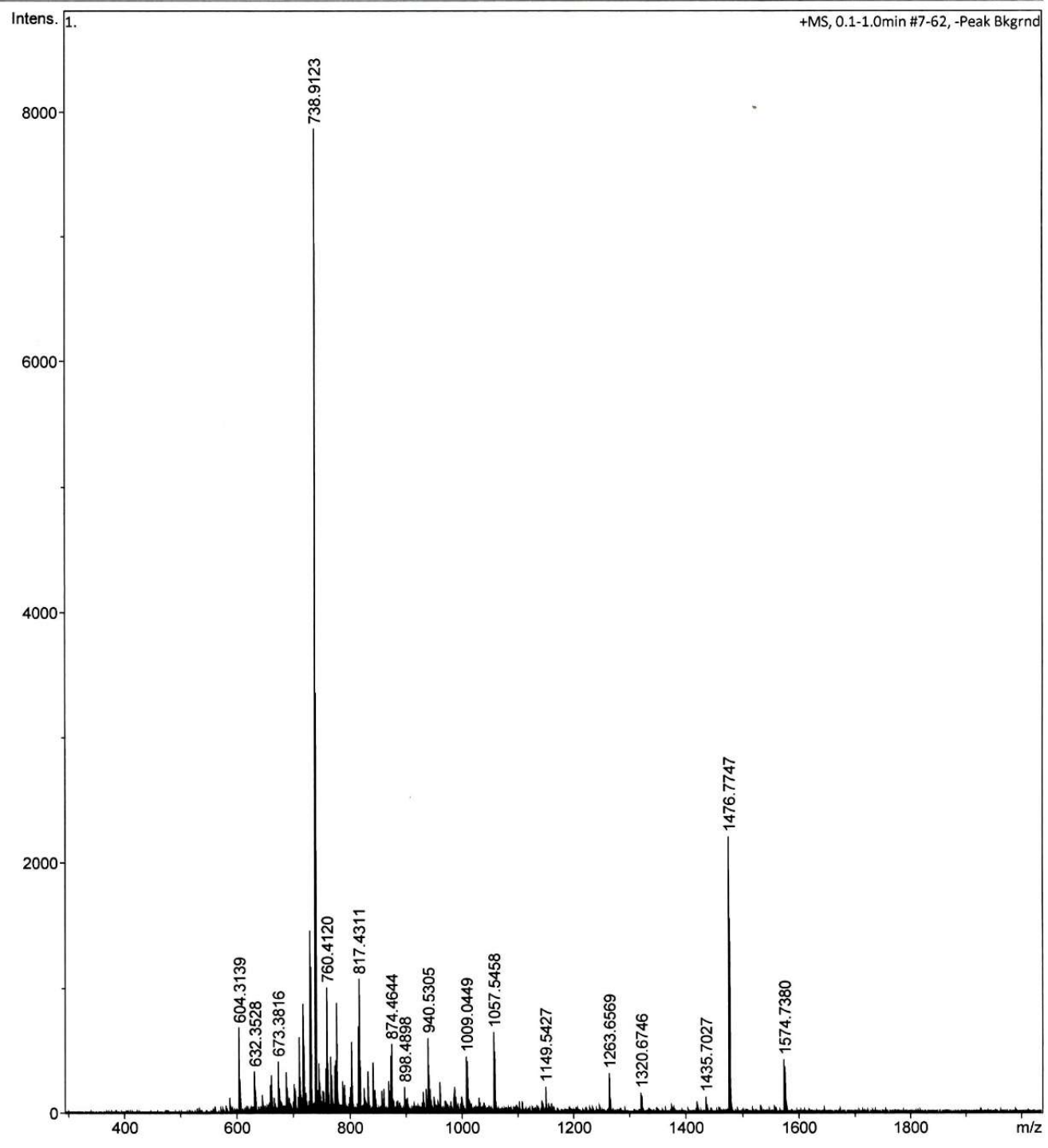

Figure S2. ESI-MS characterization of CGDEVDHGK-PPa. 

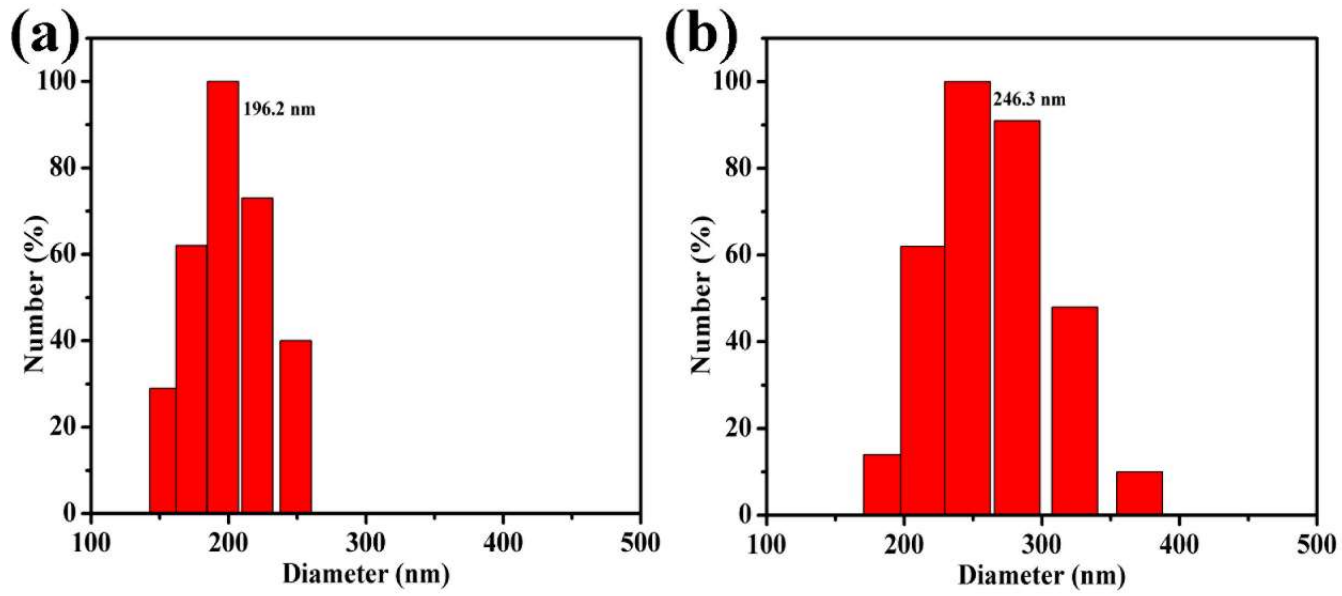

Figure S3. Dynamic light scattering (DLS) measurements of HAuNs before (a) and after linking with peptide-PPa (b).

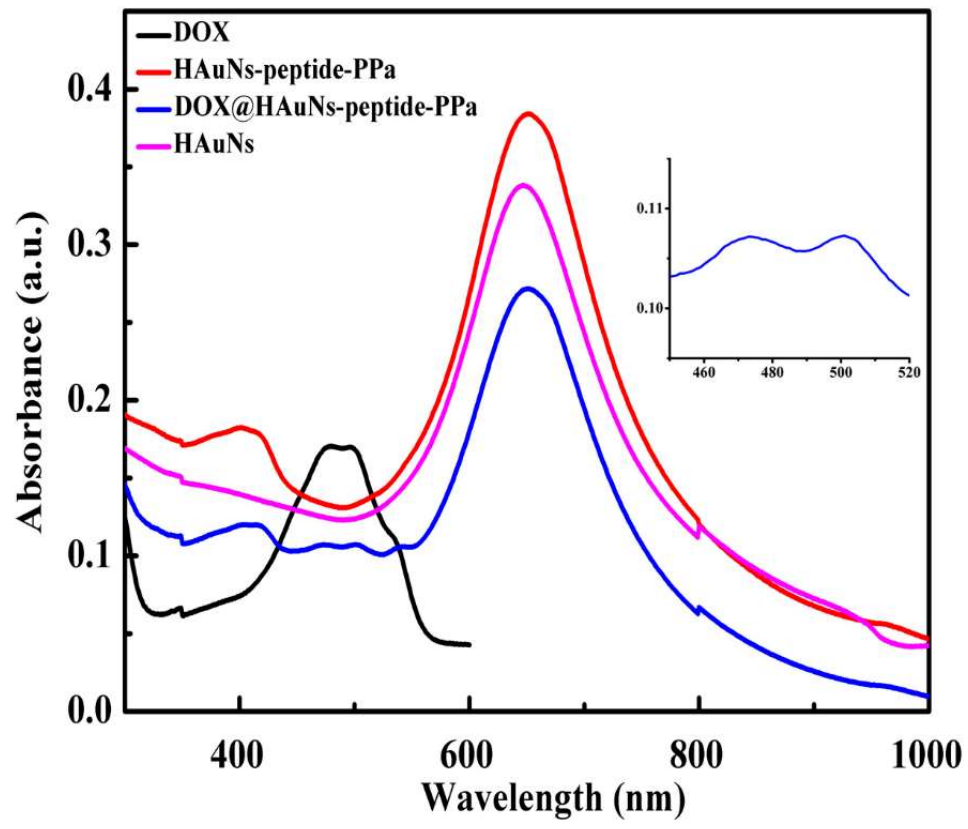

Figure S4. The UV-vis absorption spectra of HAuNs, DOX, HAuNs-peptide-PPa, and DOX@HAuNs-peptide-PPa. Inset: the UV-vis absorption spectrum of DOX@HAuNs-peptide-PPa from 450 nm to 520 nm. 


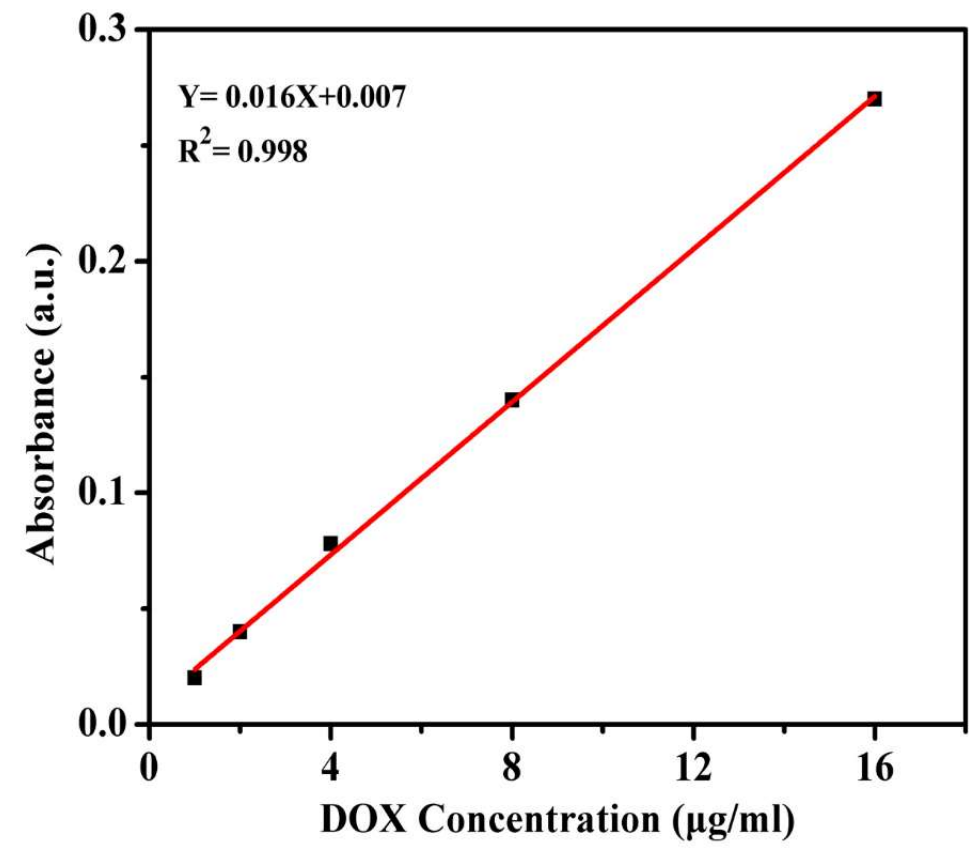

Figure S5. The linear relationship between the absorbance and the concentration of DOX. 

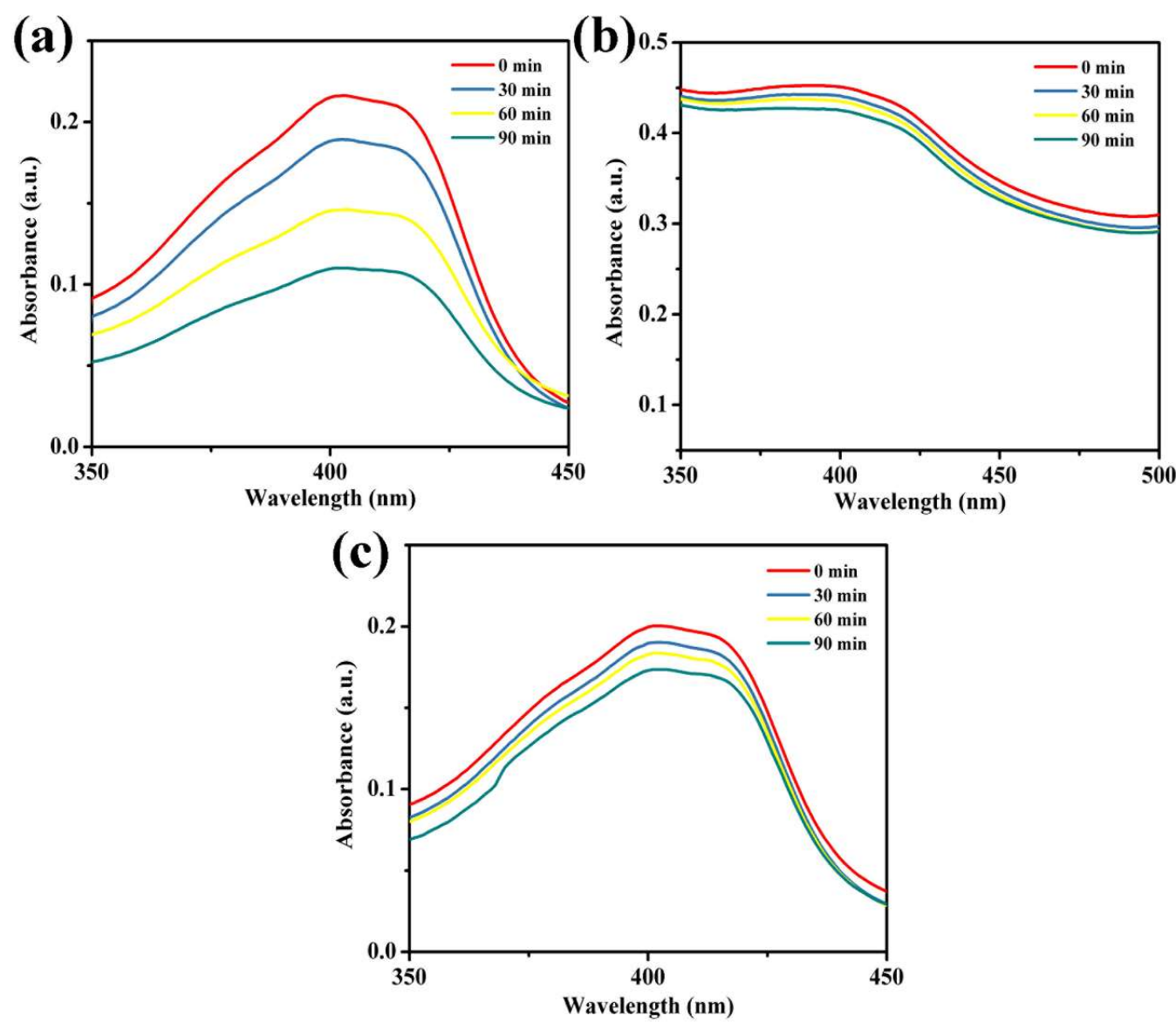

Figure S6. Absorption spectra of peptide-PPa $\left(5 \mu \mathrm{g} \mathrm{mL} \mathrm{m}^{-1} \mathrm{PPa}\right)(\mathrm{a})$, the nanoprobe containing $5 \mu \mathrm{g} \mathrm{mL}^{-1} \mathrm{PPa}$ (b) exposed to sunlight for different time intervals, and the nanoprobe exposed to sunlight, followed by treatment with $1 \mathrm{nM} \mathrm{MMP2} \mathrm{(c).}$ 

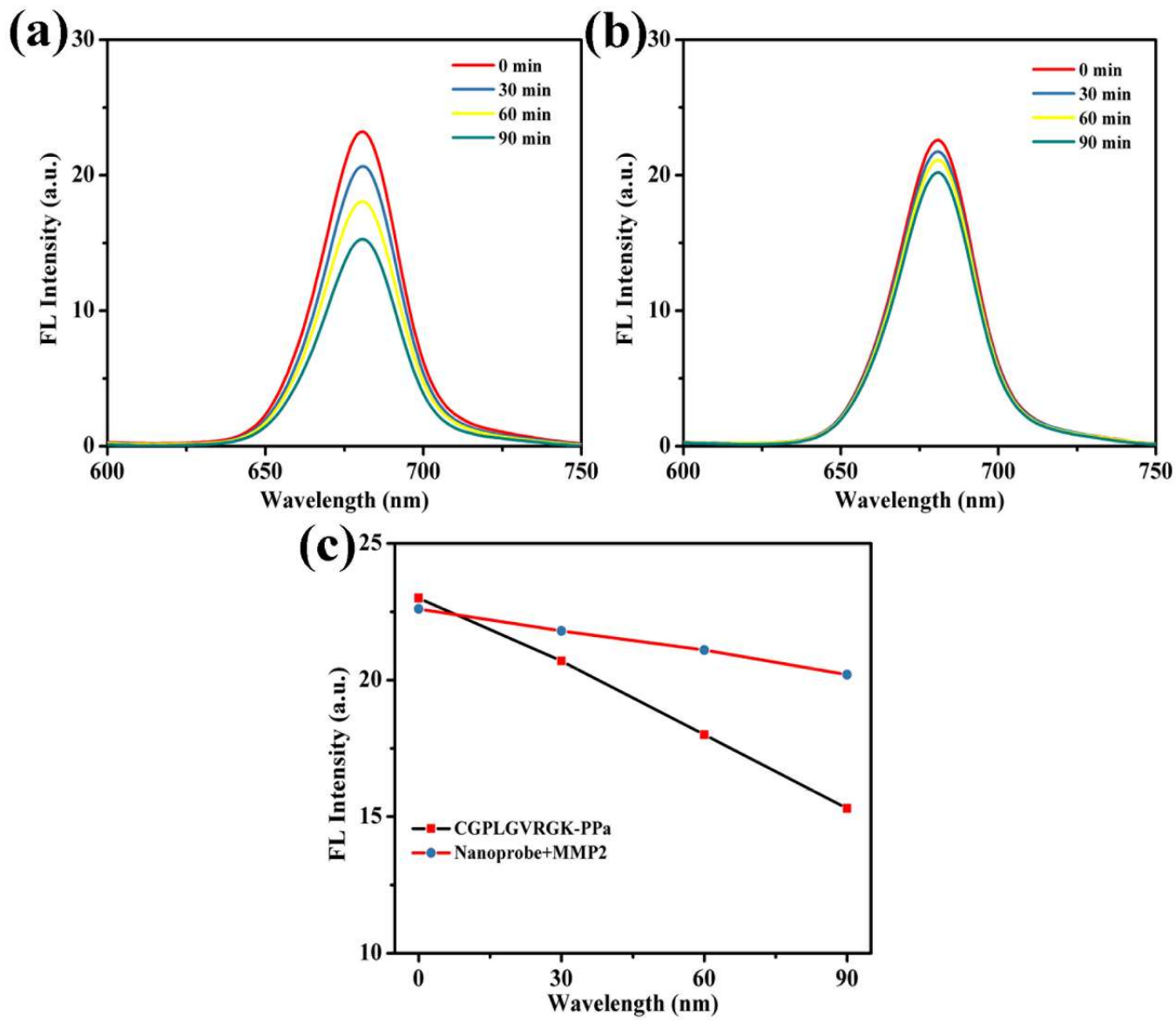

Figure S7. Fluorescence emission spectra $\left(\lambda_{\mathrm{ex}}=420 \mathrm{~nm}\right)$ of peptide-PPa (a), the nanoprobe exposed to sunlight for different time intervals, followed by treatment with $1 \mathrm{nM}$ MMP2 (b), fluorescence intensity decay of (a) and (b) at $682 \mathrm{~nm}$ (c). 

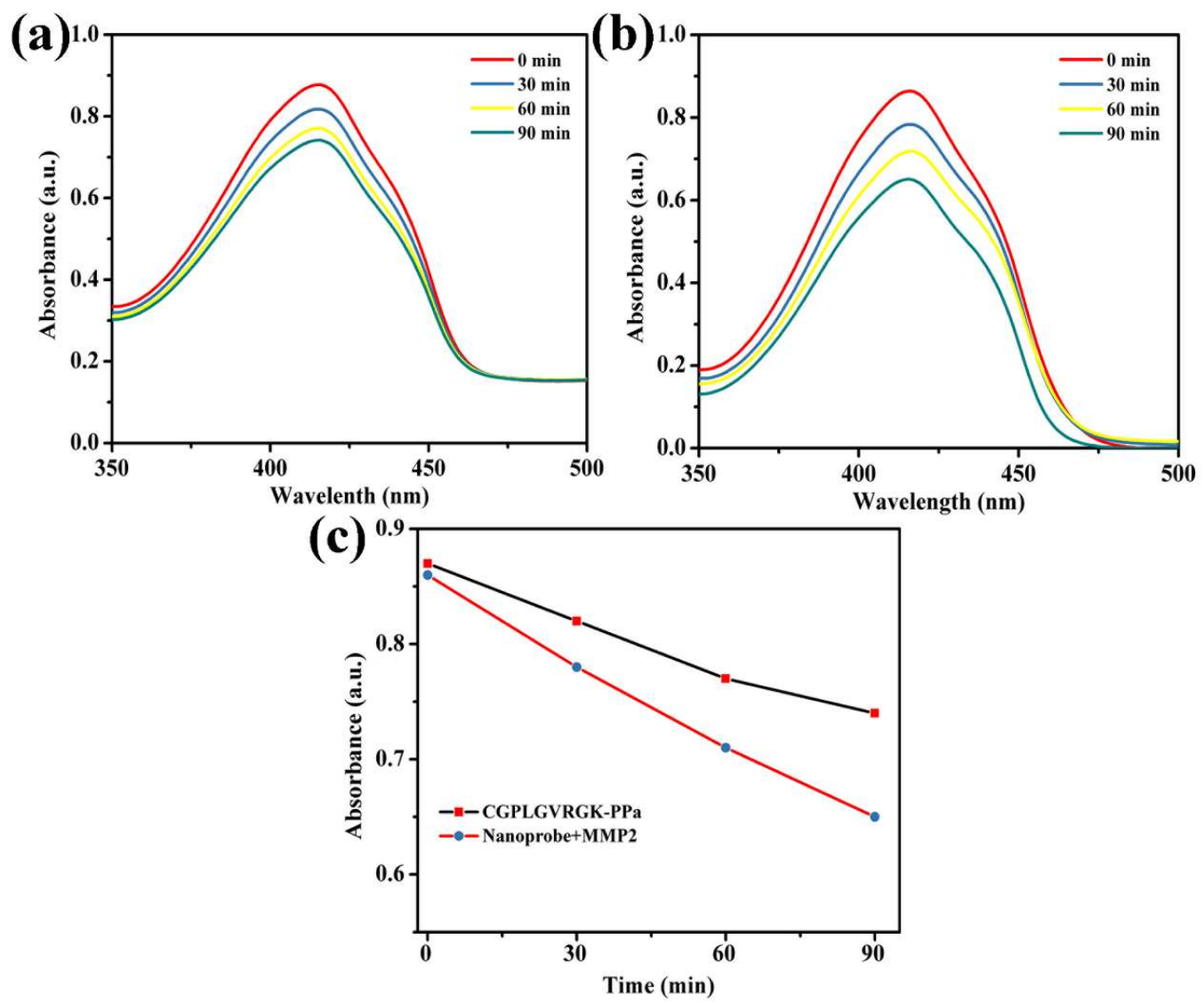

Figure S8. Absorption spectra of DPBF at $417 \mathrm{~nm}$ in solution containing the free CGPLGVRGK-PPa exposed to sunlight for different time intervals (a), the nanoprobe exposed to sunlight for different time intervals, followed by treatment with $1 \mathrm{nM}$ MMP2 (b), and the absorbance decay of DPBF at $417 \mathrm{~nm}$ of (a) and (b) under the irradiation for different time intervals $(0,30,60,90 \mathrm{~min})(\mathrm{c})$. 

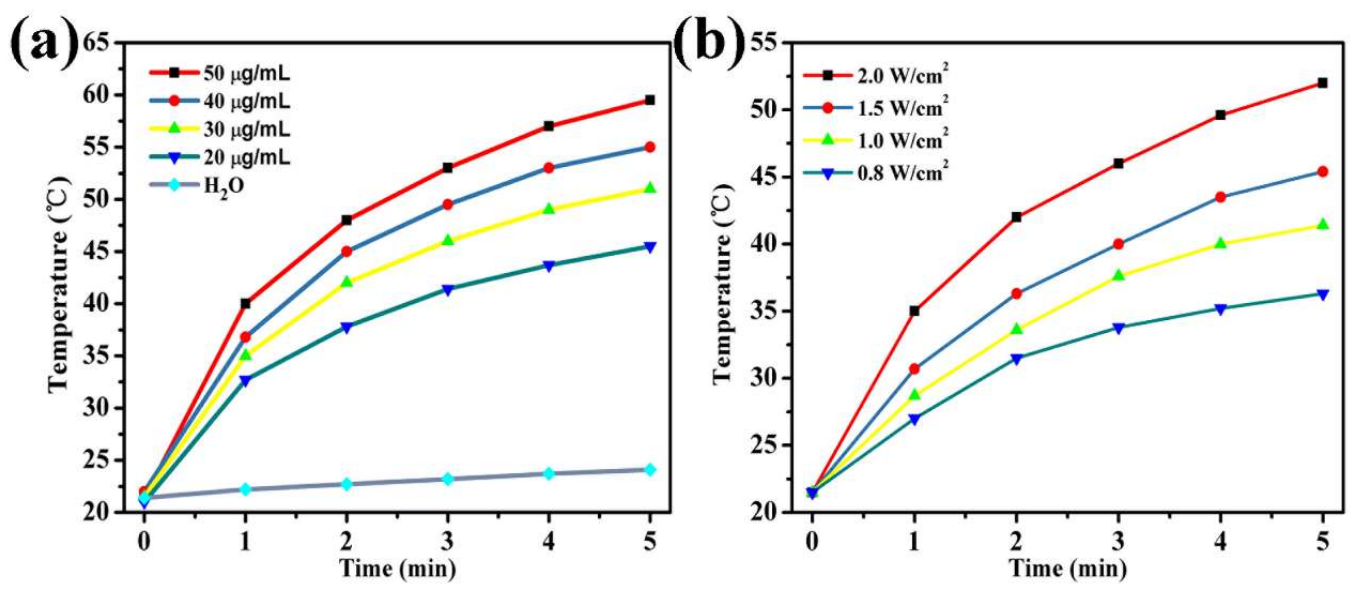

Figure S9. (a) photothermal (PT) conversion characterizations of HAuNs aqueous solution with various concentrations under $2.0 \mathrm{~W} \mathrm{~cm}^{-2} 660 \mathrm{~nm}$ laser irradiation for 5 min. (b) PT conversion characterizations of the HAuNs solution (the concentration of HAuNs is $30 \mu \mathrm{g} \mathrm{mL}^{-1}$ ) under various power density of $660 \mathrm{~nm}$ laser irradiation for 5 $\min$. 

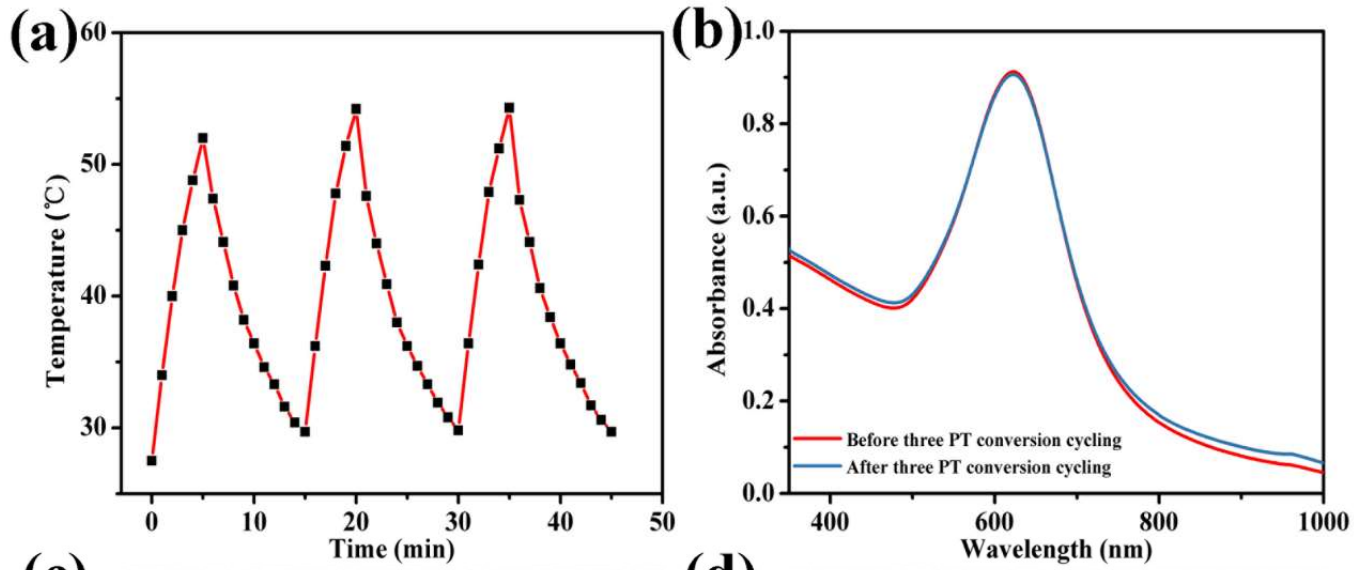

(c)

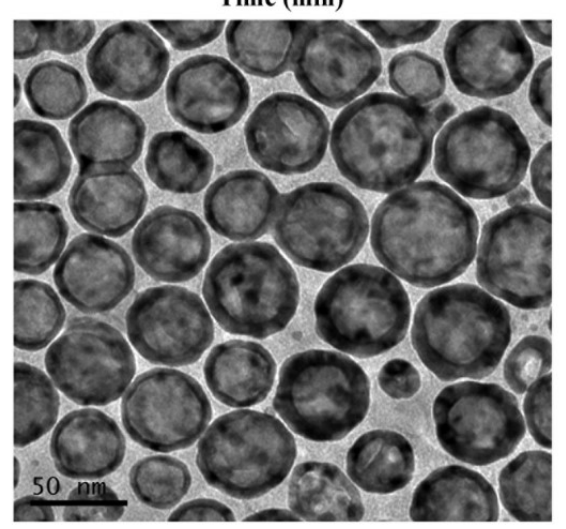

(d)

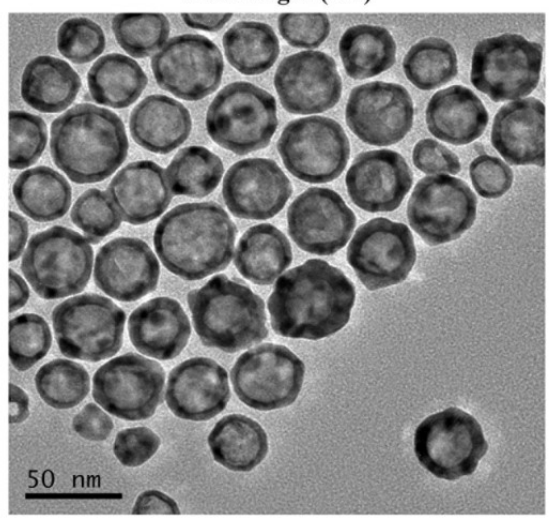

Figure S10. (a) Temperature curves of HAuNs solution $\left(25 \mu \mathrm{g} \mathrm{mL}^{-1}\right)$ monitored with thermal imager during three rounds of $660 \mathrm{~nm}$ laser-induced heating and cooling cycles. (b) The absorption spectra of HAuNs before and after three PT conversion cycling. TEM images of HAuNs before (c) and after three PT conversion cycling (d). 
(a)

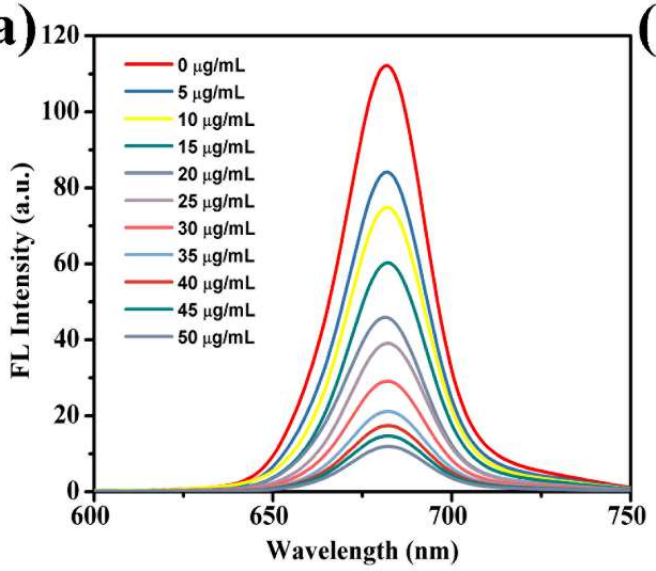

(b)

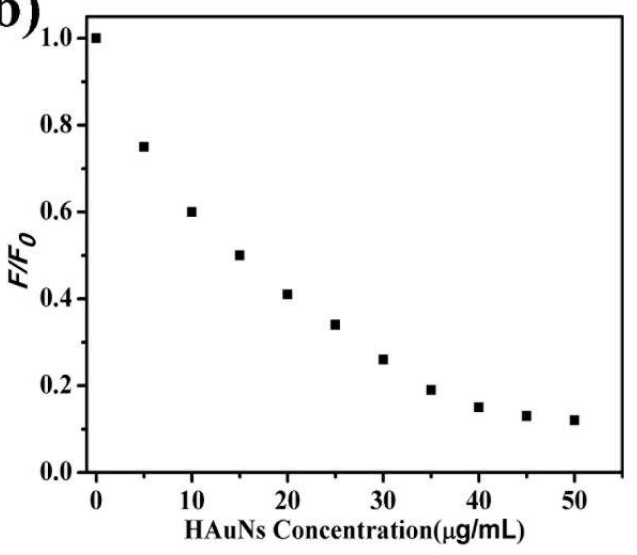

Figure S11. (a) Fluorescence emission spectra $\left(\lambda_{\mathrm{ex}}=420 \mathrm{~nm}\right)$ of CGPLGVRGK-PPa $(50 \mu \mathrm{M})$ reacted with different concentrations of HAuNs $(0,5,10,15,20,25,30,35$, $\left.40,45,50 \mu \mathrm{g} \mathrm{mL}^{-1}\right)$. (b) The variation of the fluorescence intensity ratios $\left(F / F_{0}\right)$ at 682 $\mathrm{nm}$ versus the concentration of HAuNs from 0 to $50 \mu \mathrm{g} \mathrm{mL}-1 . F_{0}$ is initial fluorescence intensity of CGPLGVRGK-PPa at $682 \mathrm{~nm}$, and $F$ is the fluorescence intensity of CGPLGVRGK-PPa at $682 \mathrm{~nm}$ after reaction with HAuNs.

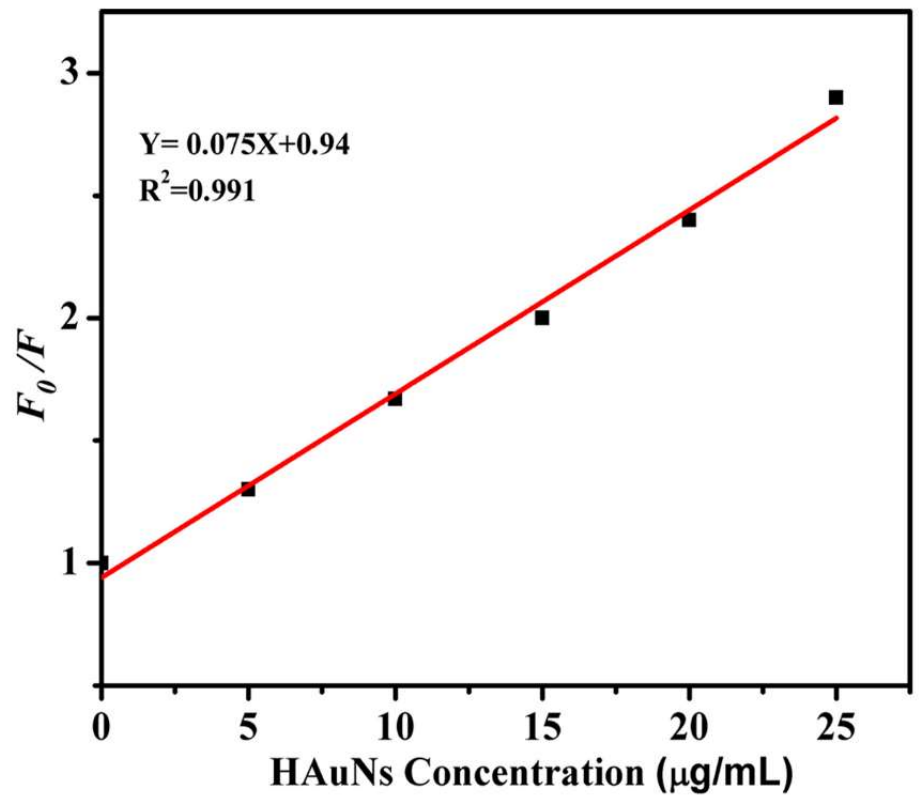

Figure S12. Stern-Volmer equation between $F_{0} / F$ and the concentration of HAuNs. 


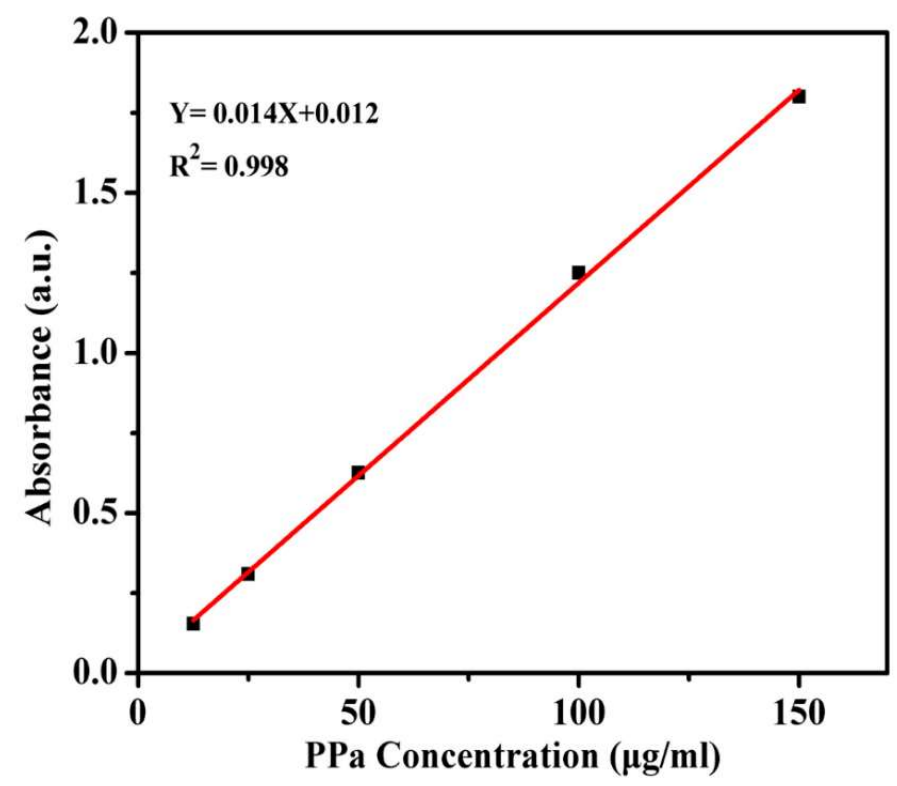

Figure S13. The linear relationship between the absorbance and the concentration of $\mathrm{PPa}$.

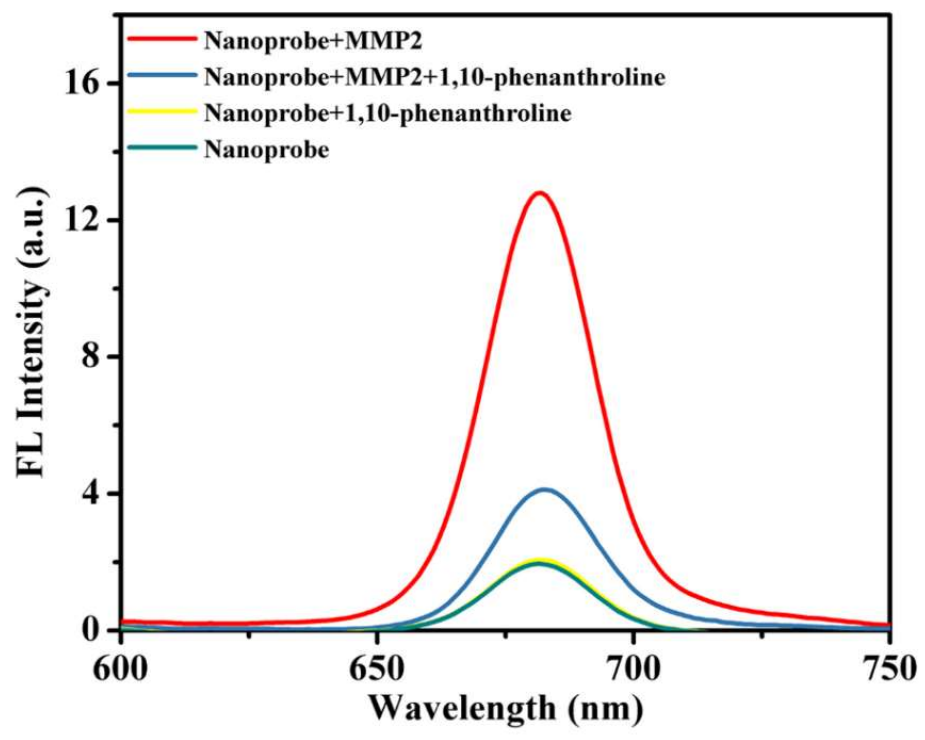

Figure S14. Fluorescence emission spectra of the nanoprobe, the nanoprobe + MMP2 $(0.5 \mathrm{nM})$, the nanoprobe $+\mathrm{MMP} 2(0.5 \mathrm{nM})+1,10$-phenanthroline $(10 \mu \mathrm{M})$, and the nanoprobe $+1,10$-phenanthroline $(10 \mu \mathrm{M})$. 


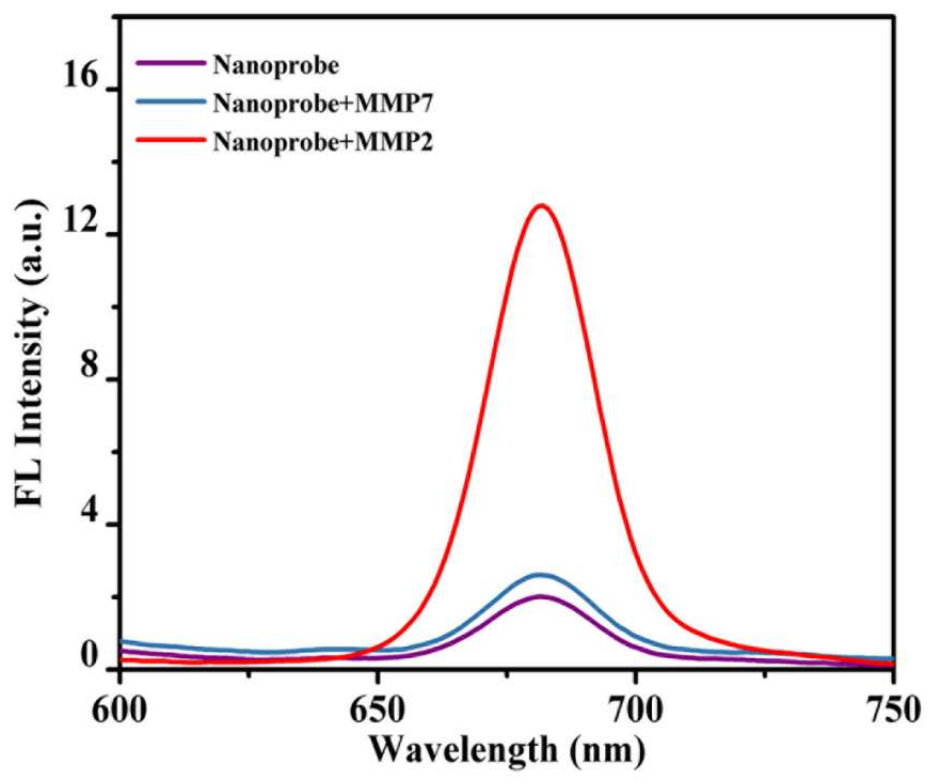

Figure S15. Fluorescence emission spectra of the nanoprobe, the nanoprobe + MMP2 $(0.5 \mathrm{nM})$ and the nanoprobe + MMP7 $(0.5 \mathrm{nM})$.

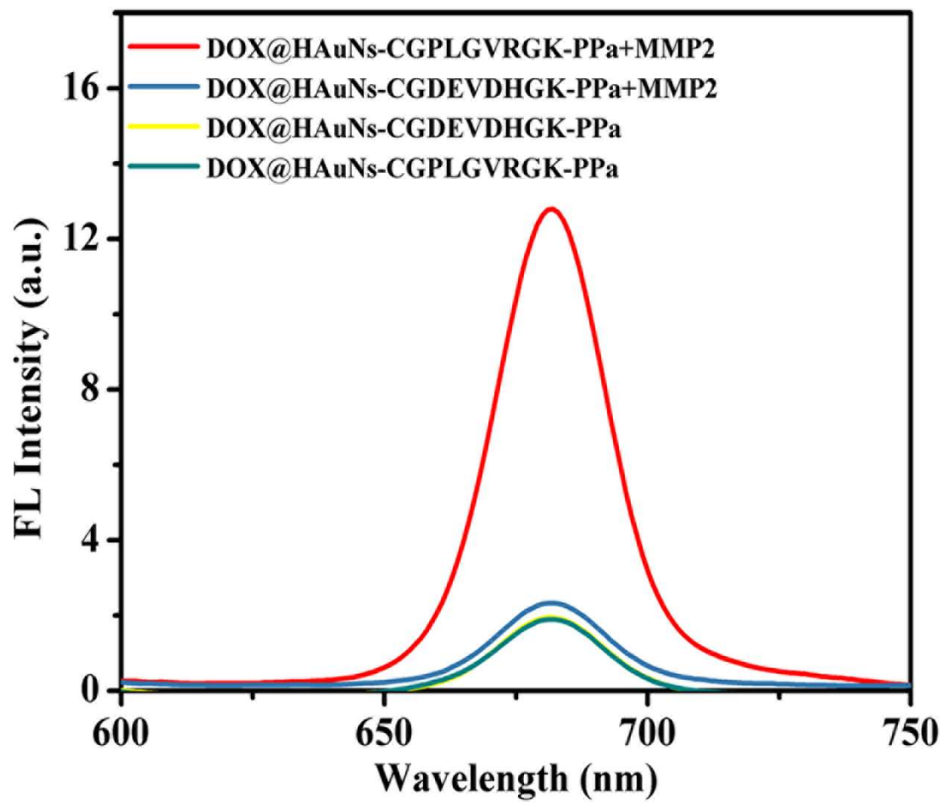

Figure S16. Fluorescence emission spectra of the nanoprobe, the nanoprobe + MMP2 (0.5 nM), HAuNs-CGDEVDHGK-PPa, and HAuNs-CGDEVDHGK-PPa + MMP2 (0.5 nM). 


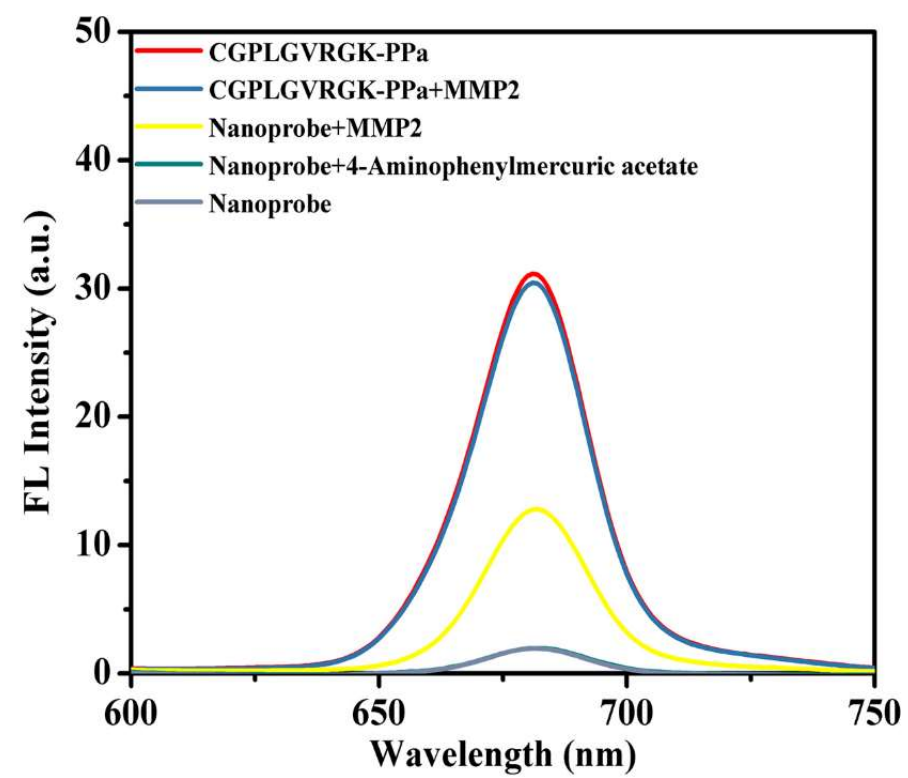

Figure S17. Fluorescence emission spectra of CGPLGVRGK-PPa, CGPLGVRGKPPa + MMP2 $(0.5 \mathrm{nM})$, the nanoprobe, the nanoprobe + MMP2 $(0.5 \mathrm{nM})$, and the nanoprobe +4 -Aminophenylmercuric acetate $(2.5 \mathrm{mM})$.

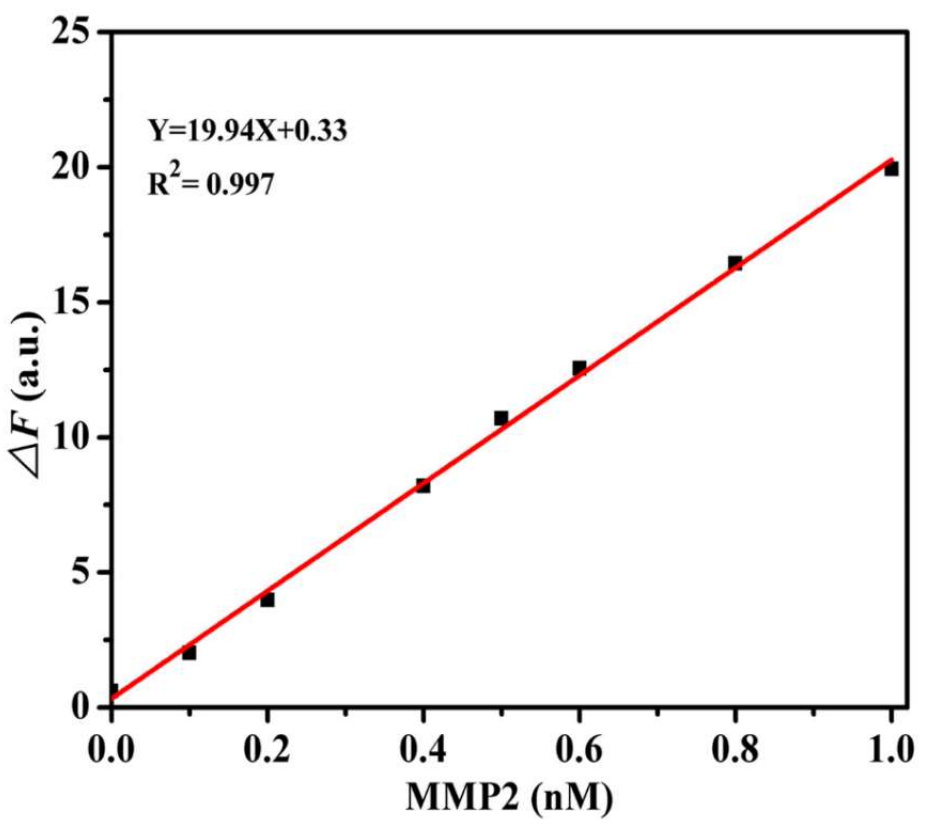

Figure S18. The linear relationship between the $\Delta F$ and the concentration of MMP2 from 0 to $1 \mathrm{nM}$. 


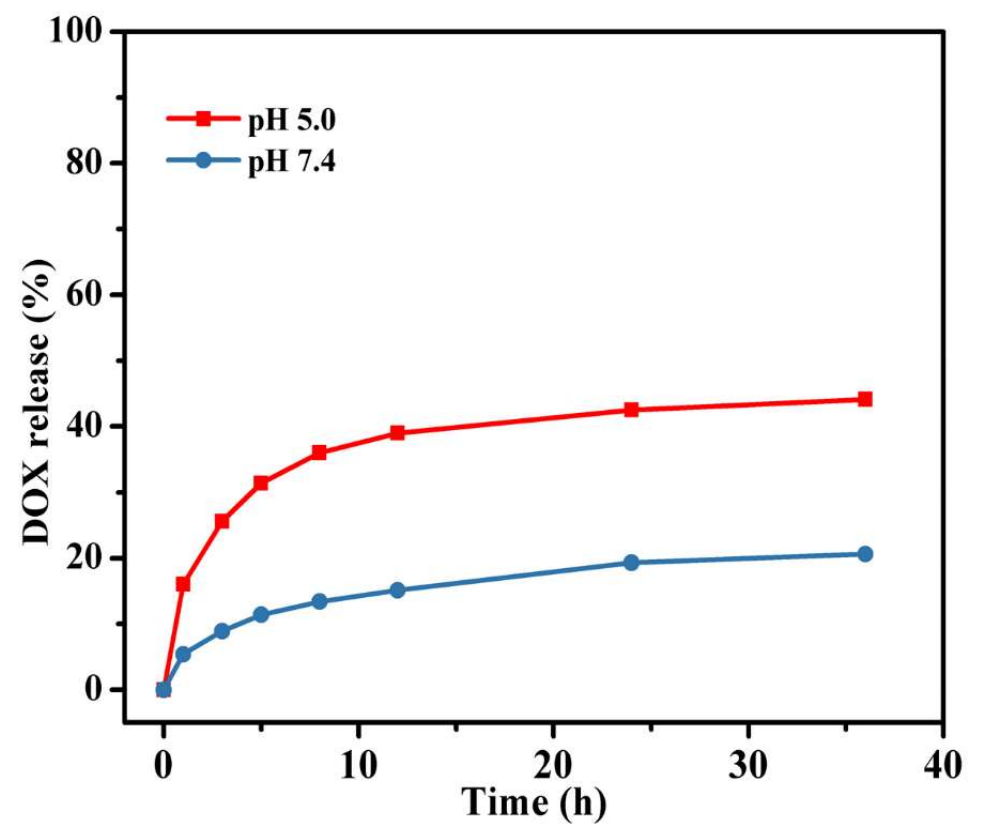

Figure S19. DOX release efficiency of DOX@HAuNs-peptide-PPa at different pH values after treatment with MMP2.

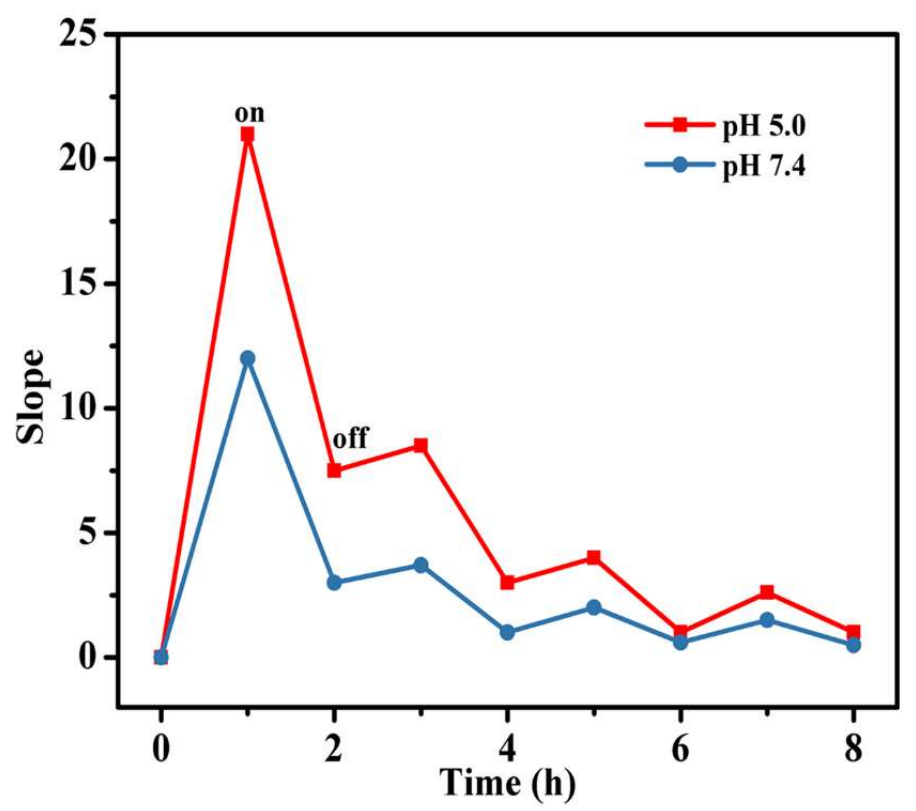

Figure S20. The slope of DOX release efficiency of DOX@HAuNs-peptide-PPa with $660 \mathrm{~nm}$ irradiation on or off every $1 \mathrm{~h}$. 

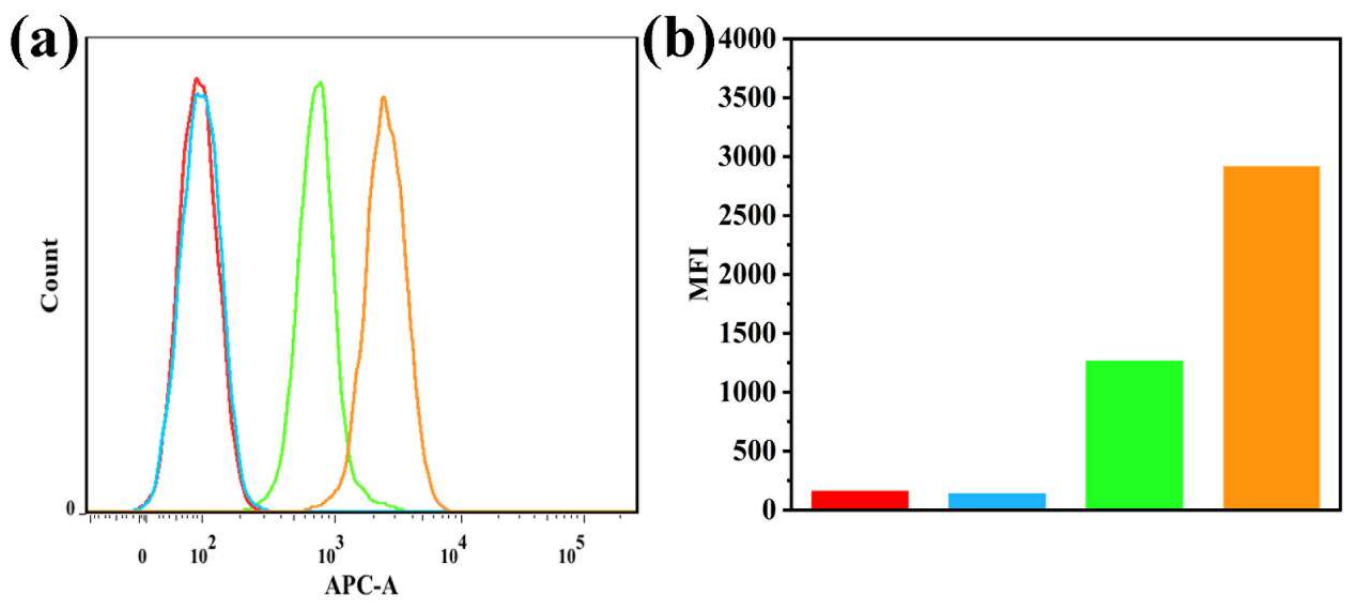

Figure S21. (a) Flow cytometric analysis of L02 cells (red line), HepG2 cells (blue line), L02 cells treated with nanoprobe (green line) and HepG2 cells treated with nanoprobe (brown line). (b) Mean fluorescence intensity (MFI) of L02 cells (red), HepG2 cells (blue), L02 cells treated with nanoprobe (green) and HepG2 cells treated with nanoprobe (brown).

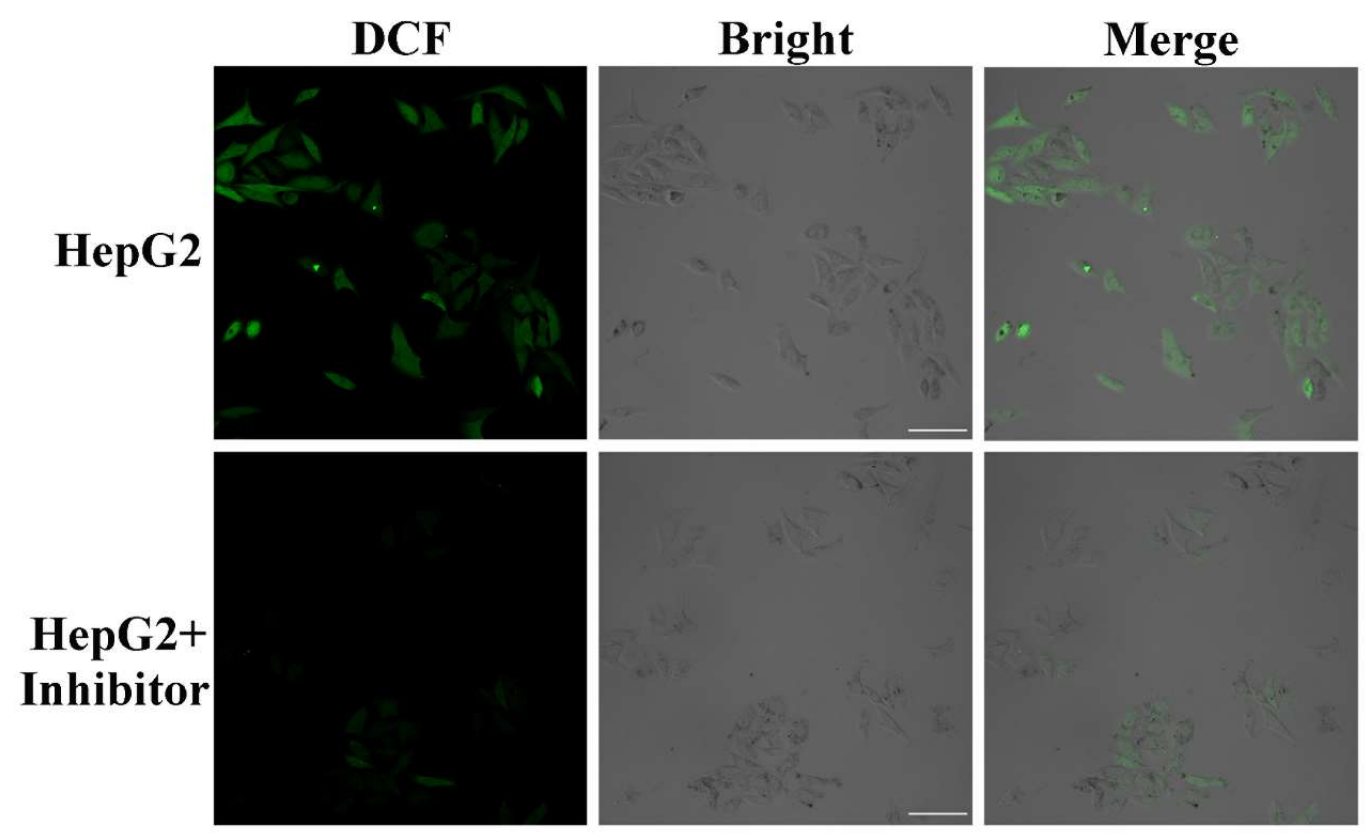

Figure S22. CLSM images of ${ }^{1} \mathrm{O}_{2}$ generation in $\mathrm{HepG} 2$ cells treated with nanoprobe, MMP2 inhibitor followed by treated with nanoprobe under $660 \mathrm{~nm}$ laser irradiation; scale bar $=50 \mu \mathrm{m}$ 


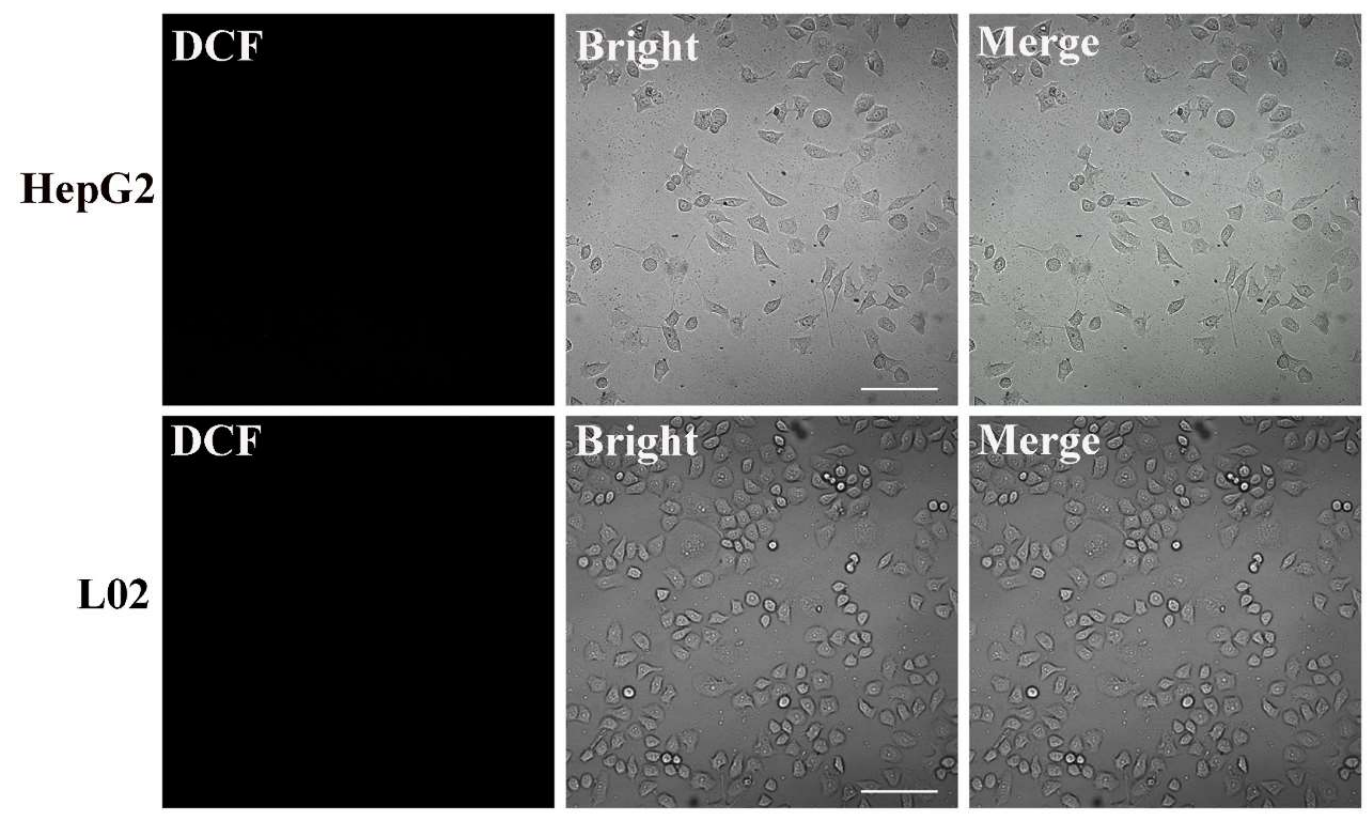

Figure S23. CLSM images of HepG2 cells and L02 cells incubated with DCFH-DA under $660 \mathrm{~nm}$ laser irradiation. $\left(\lambda_{\mathrm{ex}} / \lambda_{\mathrm{em}}=488 / 525 \mathrm{~nm}\right)$; scale bar $=150 \mu \mathrm{m}$. 


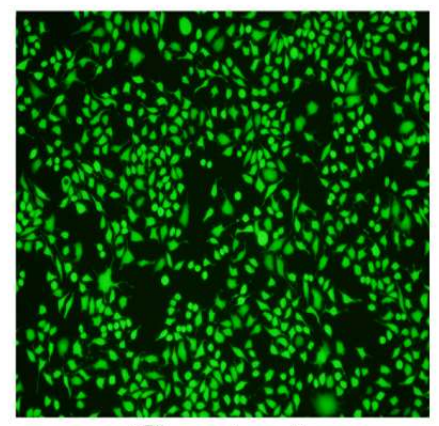

Control

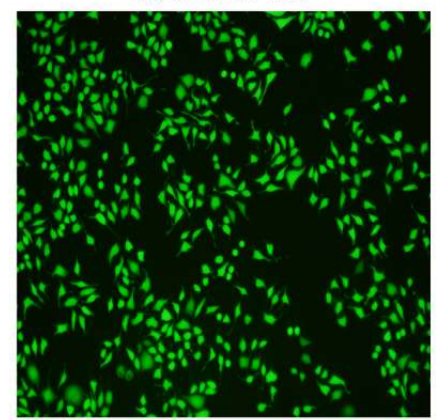

\section{HAuNs-peptide-PPa Nanoprobe}

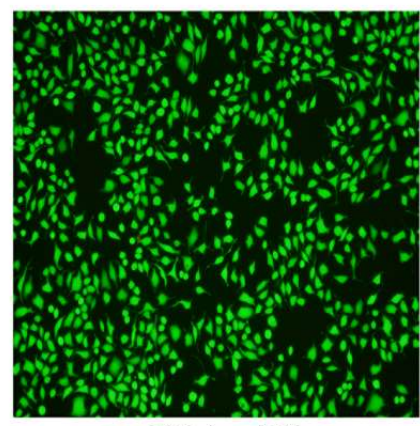

HAuNs

Figure S24. The fluorescence images of HepG2 cells co-incubated with calcein AM and propidium iodide untreated and treated with $660 \mathrm{~nm}$ laser, HAuNs, HAuNs-peptide-PPa, and the nanoprobe (5 $\mu \mathrm{M} \mathrm{PPa)}$. 

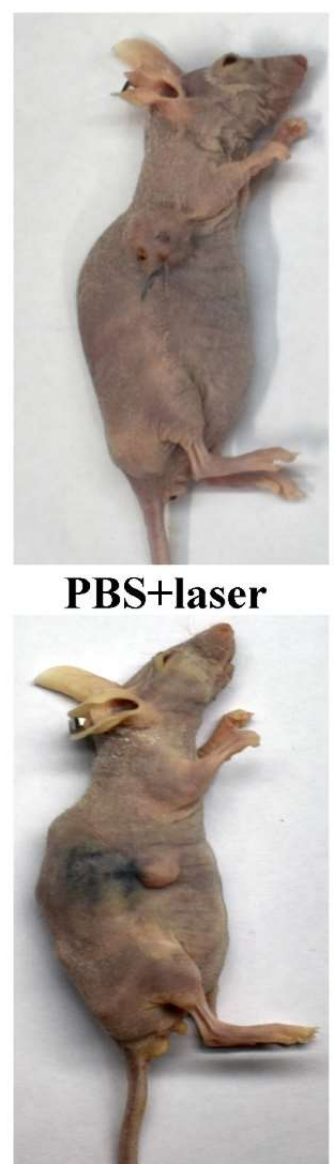

PDT/PTT

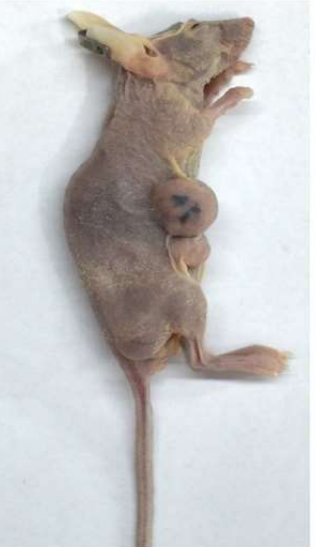

Nanoprobe

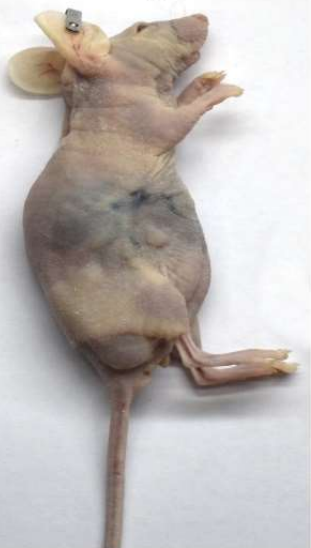

PDT/PTT/CT

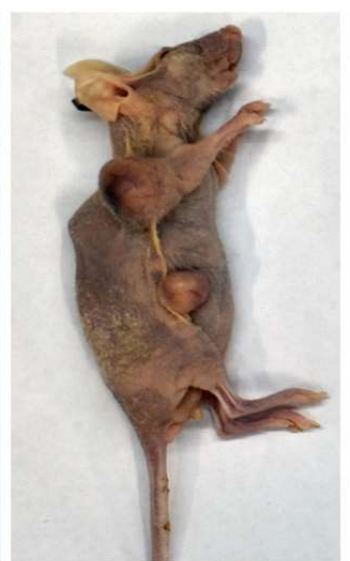

PDT

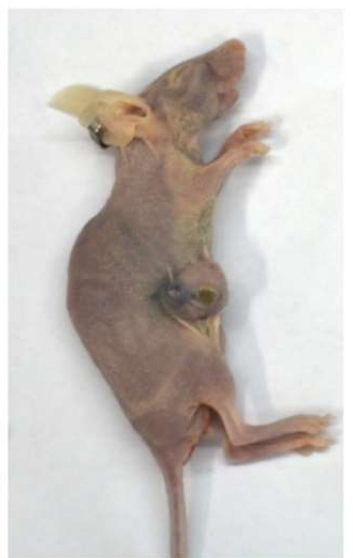

PTT

Figure S25. Representative photographs of tumor-bearing mice after 3 weeks of different treatments. 